\title{
Role requirements in academic recruitment for construction and engineering
}

\section{Citation for published version:}

Pilcher, N, Galbrun, L, Craig, N, Murray, M, Forster, AM \& Tennant, S 2020, 'Role requirements in academic recruitment for construction and engineering', European Journal of Engineering Education. https://doi.org/10.1080/03043797.2020.1725451

Digital Object Identifier (DOI):

10.1080/03043797.2020.1725451

Link:

Link to publication record in Heriot-Watt Research Portal

Document Version:

Peer reviewed version

Published In:

European Journal of Engineering Education

\section{Publisher Rights Statement:}

This is an Accepted Manuscript of an article published by Taylor \& Francis in European Journal of Engineering Education on 12/02/20, available online: https://doi.org/10.1080/03043797.2020.1725451

\section{General rights}

Copyright for the publications made accessible via Heriot-Watt Research Portal is retained by the author(s) and / or other copyright owners and it is a condition of accessing these publications that users recognise and abide by the legal requirements associated with these rights.

\section{Take down policy}

Heriot-Watt University has made every reasonable effort to ensure that the content in Heriot-Watt Research Portal complies with UK legislation. If you believe that the public display of this file breaches copyright please contact open.access@hw.ac.uk providing details, and we will remove access to the work immediately and investigate your claim. 


\title{
Role requirements in academic recruitment for Construction and Engineering Nick Pilcher ${ }^{a}$, Laurent Galbrun ${ }^{b}$, Nigel Craig ${ }^{c}$, Mike Murray $^{d}$, Alan M. Forster ${ }^{b}$ and Stuart Tennant ${ }^{\mathrm{e}}$
}

\author{
${ }^{a}$ The Business School, Edinburgh Napier University, Edinburgh, UK; ${ }^{b}$ Institute for Sustainable Building Design, Heriot- \\ Watt University, Edinburgh, UK; ' ${ }^{C}$ School of Engineering and the Built Environment, Glasgow Caledonian University, \\ Glasgow, UK; ${ }^{d}$ Department of Civil and Environmental Engineering, University of Strathclyde, Glasgow, UK; ${ }^{\mathrm{e}} \mathrm{School}$ \\ of Computing, Engineering and Physical Sciences, University of the West of Scotland, Paisley, UK
}

\begin{abstract}
Two ongoing and recurrent debates in the employment of academic staff are (1) how much industry experience should faculty staff have? and (2) what priority is given to research, teaching or both? Such debates take place worldwide and are particularly relevant to vocational subject areas. Through a statistical analysis of circa 200 job adverts for lecturer / assistant professor, senior lecturer / associate professor, and professor / full professor positions in Construction and Engineering posts in the UK, this paper investigates the essential and desirable attributes required for 'research', 'teaching' and 'overall requirements'. The analysis shows institutions unmistakably focus on, and coherently recruit for research, but demonstrate very little reasoned approach to recruiting for teaching. Indeed, findings identify 'administration' as the key teaching priority. Further empirical analysis demonstrates no significant difference in recruitment strategy before and after the introduction of the Teaching Excellence Framework, despite its aim to put teaching excellence to the fore.
\end{abstract}

\section{ARTICLE HISTORY}

Received 30 August 2019

Accepted 30 January 2020

\section{KEYWORDS}

Construction and Engineering; recruitment; research; teaching; employment attributes

\section{Introduction}

Higher Education (HE) recruitment strategies have arguably reflected the growing importance of research-led activities (Blackmore, Blackwell, and Edmondson 2016). This emphasis on research and by extension employment criteria has altered academic staff identity. The institutional shift in recruitment policy has resulted in 'faculty appointment, promotion and tenure systems that reinforce an academic culture that does not appropriately prioritise and reward teaching excellence' (Graham 2018, 34).

In the UK, emphasis on HE research output has been longstanding. Institutional aspirations for research 'intensification' and the associated benefits that result from government funding in the UK HE sector arguably commenced in earnest with the Research Assessment Exercise (RAE) in 1986. Since the inaugural RAE in 1986, there have been a number of RAE's culminating in the most recent manifestation of the Research Excellence Framework (REF) in 2014 and forthcoming REF 2021. For RAE and more recently REF, university research output is judged by expert panels and research impact considered to be of the highest quality is accorded the greatest proportion of government funding. Indeed, the economic rationale for REF is compelling, given that the value of an impact case study would be significant with a high quality ('four star') impact study being 'worth' nearly four high-quality academic papers in money terms, approximately $£ 120,000$ ' (Power 2015, 46). The allure of high-quality journal papers, demonstrable impact case studies and successful PhD student throughput is omnipresent in research-oriented institutions' metrics.

Somewhat predictably, and given the neoliberal environment, UK universities have focused on aligning recruitment procedure and practice with this policy in a drive to improve university access to alternative income streams. Whilst considerable efforts are undertaken to attract research active academics, a paradox is apparent insomuch as the largest proportion of an academic institution's income generation is associated with teaching activities (Olive 2017). This situation appears myopic as these appointments arguably take the institution further away from supporting their core business income stream if student satisfaction is linked to industrially experienced staff that better facilitate subject contextualisation. Institutional counterbalance is notionally offered by newly appointed academics (both research- and teaching-oriented) being required to complete a Post Graduate Certificate in Academic Practice (PGCAP) or Post Graduate Certificate in Teaching (PGCert) (80.5\% of the sector according to Gosling 2010). According to Cui, French, and O'Leary (2019) the introduction of the UK Teaching Excellence Framework (TEF) has put an emphasis on ensuring that newly appointed and existing lecturers undertake such qualifications, with the sector seeing these as an integral component of staff development. Despite such a requirement however, the ramifications for recruitment practice is that individuals with industry experience seeking employment opportunities in the $\mathrm{HE}$ 
sector will be overlooked in favour of candidates with PhDs and the potential to secure research funding through grant income or REF assigned block funding based on high-quality journal papers (Tennant et al. 2015). It is not our aim to denigrate such qualifications as, having a PhD and a PGCAP or a PGCert can help in understanding non-subjectspecific pedagogy of Teaching and Learning, but neither helps in contextualising learning with real world examples in the way industry experience does (Pilcher et al. 2017; Forster et al. 2017; Murray et al. 2017). It was with a specific goal of addressing the disproportionate bias towards research and away from teaching created by this researchfocused policy, that the UK government introduced the Teaching Excellence Framework in 2016 (BIS 2016; cf. Hubble 2017).

The TEF aspired to redress the imbalance between teaching and research, and tip the scales back towards the importance of teaching (Hubble 2017). Given the corporate neoliberal interpretation of students as consumers (Holligan and Shah 2017) and the importance of teaching excellence to student (customer) satisfaction (Hayward and Ongaro 2016), the performance management and measurement of teaching through student feedback gathered in the National Student Survey (Holligan and Shah 2017) became pivotal to the ideology of the UK government. The TEF accords universities an award of 'gold', 'silver' or 'bronze' based on their 'teaching' performance, and this in turn impacts on their revenue potential and the ability to charge different fee levels to students (Bell and Brooks 2019). At the same time, it aimed to reinforce the importance and prominence of teaching amongst academic staff (Perkins 2019). In theory and particularly in a context of a vocational subject such as Construction and Engineering, this 'recalibration' should have two impacts. Firstly, it should mean more individuals with industry experience offered lecturing posts especially given the importance of such knowledge to teaching (Royal Academy of Engineering 2019). Secondly, institutions when recruiting should place greater emphasis and weight upon teaching-related attributes in their advertisements. For example, there could be more of an emphasis on aspects such as the Scholarship of Teaching and Learning (Sotl) - (Boyer 1990) where the aspiration is for teaching to be considered equal to research and for academics to 'think of teaching as scholarly' (Beach 2016, 14) practice.

In this paper, a large body (200+) of Construction and Engineering (C\&E) advertisements for lecturer / assistant professor (hereafter 'lecturer'), senior lecturer / associate professor (hereafter 'senior lecturer') and professorial / full professorial (hereafter professor) roles ${ }^{1}$ in UK universities are collated and evaluated. Such roles have expectations for successful applicants to undertake work in three key areas of: research, teaching, and administration. The adverts themselves therefore provide a window on how institutions value and prioritise different areas of academic engagement and their academic staff roles and responsibilities. These advertisements are the focus here of a number of statistical analyses that are undertaken to explore potential relationships between key academic employment attributes across adverts from before the introduction of the Teaching Excellence Framework (pre-TEF) and after it (post-TEF). These analyses are undertaken to understand how eventual roles relate to the real world requirements of graduates in what is essentially a vocational subject, but also to consider whether the introduction of the Teaching Excellence Framework (TEF) has had any perceptible impact on institutions seeking to recruit more individuals with industry experience, or with teaching-related attributes and focus. In essence, to explore whether the rationale for the TEF to rebalance teaching and research has in fact translated into the reality of recruiting individuals to enact it.

Detailed analyses disclose that the key theoretical goal of the TEF to 'make teaching and research, in universities and colleges, of equal status' (Hubble 2017,4) have not had an impact upon the policy and practice of how Higher Education Institutions ( $\mathrm{HEI}^{\prime} \mathrm{s}$ ) in the UK are recruiting new academic staff members. Findings also challenge the aspiration of TEF in terms of TEF's practical ability to have achieved any rebalancing towards teaching. The statistical analyses disclose that across both pre-TEF and post-TEF adverts and with specific regard to 'research' related attributes, universities show a strikingly homogenous approach to the attributes they specify as essential and desirable. Such homogeneity clearly indicates a lack of any rebalancing. Indeed, most industry practitioners seeking a career in HE would be excluded from the recruitment process at the outset through their lack of a PhD qualification. In stark contrast to the homogeneity in attributes related to research, job adverts show an almost haphazard approach to attributes indicative of 'teaching'. Notably, this is the case for both pre-TEF and post-TEF adverts. Our findings appear to run counter to a recent UK Department for Education report evaluating the impact of the TEF which noted that ' $20 \%$ of TEF contacts reported an increased emphasis in recruiting staff with appropriate skills as a result of the TEF, while $11 \%$ of TEF Contacts reported an increased use of industry experts' (Vivian et al. 2019, 40). Nevertheless, we note that this report does not define 'appropriate skills', and also note that 'an increased use of industry experts' may not equate to the actual recruitment of permanent staff with such expertise. Indeed, as our findings show here, this certainly does not appear to be the case in C\&E. We note that whilst this paper analyses and discusses data from a UK context, issues related to sponsoring and measuring teaching excellence that the TEF aspires to achieve, echo similar efforts to promote excellence Europe wide (Gunn 2018), as seen through the explicit links between quality assurance and learning and teaching processes within European Institutions (ESG 2015).

In this paper, in the context of C\&E education, previous initial research showing TEF has had an impact on academic identity (Perkins 2019) and that professional teaching qualifications impact upon student contentment (Bell and Brooks 2019) is challenged. What the data analysis reveals is that HEl's appear to be completely heterogeneous in their comprehension of teaching goals. Conversely, continued homogeneity of attributes for research implies that 
those with industry experience, i.e. those with the professional experience and arguably well placed to deliver C\&E education and contribute to teaching excellence, will be unable to demonstrate key HE employability attributes if the current homogenous focus on research remains unchallenged.

The paper is organised as follows. First, a brief literature review highlights common debates and recruitment patterns. Second, a research methodology and sources of adverts are outlined prior to presenting and analysing the data. The discussion section discloses strong relationships for research attributes; conversely, for 'teaching' they are almost non-existent, and, significantly, display virtually no differences in pre and post-TEF adverts. Finally, the conclusion offers avenues for further research and comments on the efficacy of the Teaching Excellence Framework.

\section{Common themes in recruitment}

Burgan $(2006,142)$ contends that 'hiring new faculty - at either the junior or senior level - is one of the most important activities of any educational institution,' promising 'an influx of new life, new approaches, new ideas.' Given HEl's transformation as neoliberal endorsing, performance driven, corporate entities, Grant and Sherrington's (2006, 1) opening assertion in their book is timely - 'Why should anyone want to become an academic?' Indeed, whilst the public perception of universities remains largely 'old-school' whereby institutions focus on teaching, the reality of academic employment is frequently quite different (Erickson, Hanna, and Walker 2020). This disconnect between myth and practice manifests in HE recruitment strategy, policy, and job adverts.

Despite a paucity of research, some studies have reflected upon specific modes of communication in academic job adverts, and provide a context and useful comparison for our approach to analysing job advertisements in this article. For example, Fairclough's (1993) discourse analysis of three academic job adverts refers to institutions claiming authority over employees, and casting potential job applicants in the employee role. In one advert for Sheffield City Polytechnic (now Sheffield Hallam University) Fairclough highlights how educational management vocabulary and collocations (teaching excellence, expertise, a dynamic, forward-looking environment, progressing research, research and consultancy) arguably help construct new corporate identities. Such narrative now appears commonplace in job adverts, as reflected in other studies in other parts of the world. For example, Nuttall et al. (2013) found Australian university job adverts for teacher educators characterised by human resource management (HRM) language rather than the expectations of specific roles. Also, Pitt and Mewburn (2016) and Lavigne (2016) found similar disjuncts between key criteria and role expectations.

Until recently, links between academic achievement and practical experience endured in HE. For many HE programmes including C\&E, it was perceived beneficial to maintain and reinforce connections between classroom theory and industry practice (Forster et al. 2017). Consequently, faculty typically displayed an eclectic cohort of staff exemplifying diversity in theoretical achievements, professional engagement and personal specialism(s). This often included industry professionals, attracted by the move into academia (Becher 1989; Metcalf et al. 2005) and who frequently found industrial experience in C\&E, 'serves as at least an initial substitute for a doctoral degree' (Becher 1989, 134).

Since Becher's (1989) commentary, UK HEl's have focused recruitment more on 'research' than 'practical experience'. This has established employment pre-conditions that exclude the majority of professionals working in the C\&E industry; namely a PhD and a record of accomplishment in research publications and grant awards. Indeed, the person specification for research performance is routinely designated 'essential', (Hayward and Ongaro 2016) whereas professional membership such as the Royal Institution of Chartered Surveyors (RICS), Institution of Civil Engineers (ICE), or professional experience; is routinely judged 'desirable'. This 'research' first policy has championed the advent of the career academic (Pilcher et al. 2017; Tennant et al. 2015). To counter industry inexperience within faculty, some have argued academics should undertake industrial placement both prior to, and during their employment (Chan 2018). This viewpoint resonates closely with the Royal Academy Industrial Fellowships Scheme (2019) that asserts industry relevance in teaching.

Against this contextual backdrop, the UK government introduced the TEF, aspiring to rebalance the research teaching nexus and ensure teaching became equally valued. This is fundamental in C\&E where theory and practice are interdependent. Indeed, debates regarding the prominence of 'teaching' or 'research' are not new. Both the 1963 report into Higher Education (HMSO 1963) and the 1964 report examining University Teaching Methods (University Grants Committee 1964), known colloquially as the Robbins and Hale reports, respectively, detail concerns regarding a research-teaching divide. Robbins, 'urged that teaching should get at least as much emphasis as research' (Calhoun $2014,79)$. Hale's report was critical, suggesting promotion too often depended 'primarily on the amount of published work an individual has done' (University Grants Committee 1964, 135). This is arguably far more pronounced today with extremely high target objective metrics for promotion by research in terms of grant income, publications, citations and $\mathrm{H}$-index scores being set. Moreover, it is arguable that such objective metrics for research-oriented staff promotion, contrast greatly with more loosely defined criteria for promotion for teaching fellow status. Here, teaching-oriented promotion is often closely intertwined with administration and has very little to do with teaching quality or innovation in Teaching and Learning (cf. Ginsberg 2011, and something the results in the Data and Analysis section below confirm). 
Yet, although such concerns of research bias continued to emerge (Halsey and Trow 1971), with the advent of the first Research Assessment Exercise (RAE) in 1986 (Jump 2013), research dominance became institutionalised and legitimised. The RAE, and subsequently the REF, continues to disproportionately dictate HEl strategic decision-making in the UK, and somewhat unsurprisingly recruitment policy and practice have shifted from a traditional professional competence, to a profile that closely aligns with research competence (Cox 2009). This is manifest worldwide (e.g. Australia (Norton 2013)) and reflects HEl's growing global marketplace and an institution's drive to explore and exploit income streams other than teaching. As Collini (2018) notes, funding research through external income generation has become big business for academics, and is now increasingly written into job adverts as 'essential', although compared to Hale's time (University Grants Committee 1964) the number of publications and research grant income won has arguably increased greatly.

Many academic disciplines face similar issues and challenges; however, for disciplines with a vocational emphasis such as C\&E education the balance between the theory and the practical is more acute. Subsequent impact on engineering education, pedagogy and teaching excellence remains inconclusive. Presently, institutions are faced with a host of dilemmas regarding who to recruit: what type of qualities should be sought? Employ career academics or industrialists? Should HEl's focus on REF, TEF, or indeed University Apprenticeships (e.g. Degree/Graduate Apprenticeships)? It is questions such as these that are reflected upon in this paper. Drawing on an extensive database of recruitment advertisements for HE posts in C\&E (200+) over a three-year period, we explore and discuss what employability criteria institutions prioritise in advertisements and, further, what difference, if any, the TEF has made to the C\&E recruitment practices of $\mathrm{HE}$ institutions in the UK.

\section{Methodology}

Our data consists of C\&E advertisements in the UK for lecturer, senior lecturer, and professor. We are not the first to analyse job adverts, others have done so in cookery (Robinson et al. 2010), forestry (Bettinger and Merry 2018) and civil engineering (Gerek and Efeoglu 2015). Also, adverts in HE (Fairclough 1993; Nuttall et al. 2013; Lavigne 2016; Pitt and Mewburn 2016) have received attention.

Our data collection of C\&E advertisements ran from 2015 to 2018. The announcement of TEF towards the end of 2015 represented an opportunity to compile pre and post-TEF data sets for analysis. Whilst it is not possible to specify an exact date for a job advert written in consideration of TEF, after careful deliberation it was concluded that August 2016 represented a suitable pre-TEF cut off date. This was approximately eight months after the original green paper publication (BIS 2016). Consequently and for the purpose of data analysis, job adverts posted after this date were recognised as post-TEF. This provided a data set of circa 200 job adverts split equitably between pre and post-TEF.

Sources for adverts were primarily 'jobs.ac.uk' and Collaborative Network of Building Researchers (CNBR). Over 1,000 webpages were viewed and 202 adverts were downloaded. The vast majority related to the wider built environment and civil engineering disciplines (Construction Project Management, Quantity Surveying, Building Surveying, Planning, Real Estate, Architecture, Interior Design, Building Services Engineering, Civil Engineering, and Structural Engineering). The majority of adverts come from University institutions characterised as Post 92 . These are former Polytechnic institutions known today as the Post $92 \mathrm{~s}$ as they were given deregulated degree-awarding status in 1993 by government act. These institutions largely focus on vocational subjects. This was unintended. The aim of the paper was to analyse job adverts in the HEl sector as they appeared over time as opposed to targeting specific types of institution such as Post 92s. Rather, it is simply the case that historically, it is this category of HEI where Built Environment or Construction Departments typically reside.

The procedure for priming the job advertisements for analysis was an initial discussion amongst five of the authors rather than one (Norris 1997) to decide how this should be approached, followed by three authors then working through the adverts to extract the key information through a process of identifying and extracting the terminology used and the attributes specified. When this stage was complete all authors met again and decided upon the different categories to focus on for the empirical analysis outlined below. In preparing the adverts for analysis we were faced with the possibility of confusion, particularly at the level of 'job level descriptors', whereby a 'teaching only' type job in the C\&E field also stipulated applicants having engaged in 'pedagogic and practitioner research' and to make a 'significant contribution to professional journals'. Such individuals, although not considered 'research active' (Stern 2016) were still required to engage in scholarly activity. In this context, the Higher Education Statistic Agency (HESA 2018) definition of academic jobs is adopted as a guide, although it is only the first two categories that the job advertisements we analysed fell into:

- Teaching only staff are those whose contracts state they are employed only for teaching.

- Teaching and research staff are those whose contracts state they are employed both for teaching and research.

- Research only staff are those whose contracts state their primary academic function is research, even though they may teach a limited number of hours (up to $6 \mathrm{~h}$ per week or pro-rata for part-time staff).

- Neither teaching nor research staff is those whose contracted academic employment function is neither teaching nor research, e.g. Vice-Chancellor. 
Of the 202 adverts examined, only 4 (2\%) were for teaching only roles (Teaching Fellow / Senior Teaching Fellow). This is unrepresentative of the recent growth in new teaching only posts within HE in the UK and indeed the sideways transfer ('research inactive') of existing teaching \& research staff to teaching-only contracts before the REF 2021 (Baker 2019). The other 198 jobs we reviewed fell into the Teaching and Research category. As such, they provided an ideal window to see how teaching and research are being prioritised, and what the role of other elements, such as administration, alongside them may be (see below). To appraise the 'essential' and 'desirable' criteria, both introductory information and detailed job descriptions were reviewed. Three broad, albeit predictable categories emerged; namely:

- Qualifications and experience: for example PhD; BSc/BEng/MSc; PGCert; FHEA; Professional Chartership / Membership, professional experience.

- Research: for example high-quality journal outputs, research funding, REF returnability; PhD supervision.

- Learning and Teaching: for example curriculum design, teaching leadership, programme leadership, teaching strategy.

Empirical analysis consisted of three statistical tests. First, Pearson Correlation test to reveal correlations between Lecturer vs Senior Lecturer vs Professor adverts (see Table 4) and also correlations between pre and post-TEF adverts (see Section 4.4). Second, chi-square independence tests to identify associations between attributes used in the adverts (see Tables 5-7). Third, phi correlation tests to identify the strength of correlations identified between attributes (see Tables 5-7).

\section{Data and analysis}

In this first section, an overview of job attributes as they appeared and were conveyed in the 202 adverts collected is presented in Table 1; research attributes in Table 2 and; teaching attributes in Table 3. Following this, in the second section, Table 4 identifies correlations between Lecturer vs Senior Lecturer vs Professor adverts. In the third section, Tables 5-7 identify the statistically significant relationships between the attributes appearing in the job adverts as a whole (Table 5); within research attributes (Table 6) and within teaching attributes (Table 7). In the fourth section, results are illustrated for pre-TEF vs post-TEF for the attributes appearing in advertisements as a whole (Table 8); for research attributes (Table 9) and for teaching attributes (Table 10).

Table 1. Percentages of job attributes appearing in academic adverts.

\begin{tabular}{|c|c|c|c|c|c|c|}
\hline Ranking & Attribute & Essential vs. Desirable & Lec (\%) & SL (\%) & Prof (\%) & Overall (\%) \\
\hline 1 & Research Outputs & Desirable & 73.9 & 71.8 & 83.3 & 73.8 \\
\hline 2 & BSc / BEng / MSc & Essential (qualifications) & 72.3 & 78.9 & 50.0 & 73.3 \\
\hline 3 & Professional Experience & Essential (experience) & 58.8 & 78.9 & 25.0 & 63.9 \\
\hline 4 & Teaching Experience & Essential (experience) & 56.3 & 70.4 & 75.0 & 62.4 \\
\hline 5 & PhD & Essential (qualifications) & 62.2 & 57.7 & 83.3 & 61.9 \\
\hline 6 & Securing Research Funding & Desirable & 45.4 & 40.8 & 58.3 & 44.6 \\
\hline 7 & Chartered & Essential (qualifications) & 33.6 & 52.1 & 33.3 & 40.1 \\
\hline 7 & PgCE & Desirable & 42.9 & 42.3 & 0.0 & 40.1 \\
\hline 8 & FHEA & Desirable & 40.3 & 35.2 & 0.0 & 36.1 \\
\hline 8 & Chartered & Desirable & 43.7 & 28.2 & 8.3 & 36.1 \\
\hline 9 & $\mathrm{PhD}$ & Desirable & 24.4 & 29.6 & 8.3 & 25.2 \\
\hline 10 & PgCE & Essential (qualifications) & 21.0 & 25.4 & 33.3 & 23.3 \\
\hline 10 & FHEA & Essential (qualifications) & 16.8 & 29.6 & 50.0 & 23.3 \\
\hline 11 & Teaching Experience & Desirable & 27.7 & 15.5 & 0.0 & 21.8 \\
\hline 12 & Professional Experience & Desirable & 11.8 & 1.4 & 0.0 & 7.4 \\
\hline
\end{tabular}

Notes: Lec: Lecturer (sample size $=119$ ); SL: Senior Lecturer (sample size $=71$ ); P: Professor (sample size $=12$ ): Overall: Lec + SL + Prof (sample size = 202). 'Chartered' = member of a C\&E professional body; PgCE = Postgraduate Certificate in Education; FHEA = Fellow of the Higher Education Academy (the body in the UK responsible for a focus on teaching).

\subsection{Analysis of all advertisements}

In Tables 1-3, data is presented in ranking order, from highest to lowest overall percentage (note: acronyms and sample sizes given at the bottom of Table 1 also apply to Tables 2-3). As Table 1 shows, the highest-ranking percentage was research outputs being desirable, followed by a BSc / BEng / MSc qualification being essential, and Professional and Teaching Experience as essential. Notably, and ranked fifth, was having a PhD being essential, in around $62 \%$ of the adverts. This would arguably rule out a significant number of applicants with industry experience 
Table 2. Percentages of research attributes appearing in academic adverts.

\begin{tabular}{llllll}
\hline Ranking & Attribute & Lec (\%) & SL (\%) & Prof (\%) & Overall (\%) \\
\hline 1 & Contribute to Research & 89.0 & 90.3 & 83.3 & 89.1 \\
2 & Research Funding & 54.2 & 51.4 & 83.3 & 55.0 \\
3 & Journals / Publications / Quality outputs & 54.2 & 50.0 & 66.7 & 53.5 \\
4 & PhD Supervision & 51.7 & 38.9 & 83.3 & 49.0 \\
5 & Recognised Research & 35.6 & 43.1 & 75.0 & 40.6 \\
6 & REF & 18.6 & 11.1 & 83.3 & 19.8 \\
7 & International Profile & 11.0 & 12.5 & 75.0 & 15.3 \\
8 & Multi-Disciplinary Research & 7.6 & 11.1 & 41.7 & 10.9 \\
9 & Culture & 1.7 & 1.4 & 25.0 & 3.0 \\
10 & Research Strategy & 1.7 & 0.0 & 8.3 & 1.5 \\
\hline
\end{tabular}

Table 3. Percentages of teaching attributes appearing in academic adverts.

\begin{tabular}{llllll}
\hline Ranking & Attribute & Lec (\%) & SL (\%) & Prof (\%) & Overall (\%) \\
\hline 1 & Administration & 78.8 & 83.3 & 25.0 & 77.2 \\
2 & LTAS / Frameworks & 69.5 & 77.8 & 50.0 & 71.3 \\
3 & Curriculum & 66.9 & 70.8 & 41.7 & 66.8 \\
4 & External Body / Industry Facing & 37.3 & 43.1 & 66.7 & 41.1 \\
5 & Leadership & 20.3 & 30.6 & 75.0 & 27.2 \\
6 & VLEs & 27.1 & 23.6 & 25.0 & 25.7 \\
7 & Pedagogic Development & 17.8 & 16.7 & 16.7 & 17.3 \\
8 & Innovative Subject Matter & 5.9 & 15.3 & 16.7 & 9.9 \\
9 & Strategic & 4.2 & 8.3 & 33.3 & 7.4 \\
\hline
\end{tabular}

from applying. It is also notable that for Professorship, Professional Experience was accorded very low priority compared to Research Outputs and securing Research Funding.

In Table 2 there appears a clear difference in relation to research for Lecturer and Senior Lecturer, and Professor. The latter contains, perhaps unsurprisingly, a far greater weight towards funding, PhD supervision, Recognised Research, REF, and International Profile. Over half the adverts were looking for applicants with research publications and a PhD, again appearing to 'rule out' those with an industry or professional based background applying, as they have probably rarely been in a position to consider publications.

In Table 3, perhaps the most notable factor is that, although the focus is supposedly on 'teaching' attributes, VLEs (Virtual Learning Environments) but in particular 'Pedagogic Development' and 'Innovative Subject Matter' rank very low on the list compared to 'Administration', 'LTAS/Frameworks' (Learning, Teaching and Assessment Strategy) or 'Curriculum'. Although it is only speculative to suggest so, if the UK Government wished to redress the balance towards teaching, and offered students a choice of prioritising 'Administration ${ }^{2}$ ' or 'Innovative Subject Matter' for qualities in their lecturers, they would be unlikely to choose the former. Indeed, it could be argued from the data provided in Table 3, that 'Lecturer' and 'Senior Lecturer' are considered 'catch all' roles for what are quintessentially 'glorified administrators' whose primary activities are increasingly removed from frontline teaching responsibilities.

\subsection{Correlations between roles}

In Table 4, Pearson correlation coefficients have been calculated between the percentage results of 'Lec' vs. 'SL' vs. 'Prof' given in Table 1 for (a), Table 2 for (b) and Table 3 for (c). Here, results show a very high and statistically significant correlation between Lecturer and Senior Lecturer adverts $(r>0.8$ and $p<0.01)$, whilst correlations between Lecturer and Professor adverts, and between Senior Lecturer and Professor adverts, show weaker correlations $(r<0.7)$ and higher $p$-values $(p>0.01)$. Correlations are still statistically significant for job (Table $4(a))$ and research (Table 4(b)) attributes $(p<0.05)$, but not for teaching attributes $(p>0.05)$. In other words, whilst teaching and research expectations are comparable for Lecturer and Senior Lecturer positions, there is a clear difference with Professorial positions, in particular regarding teaching expectations. For further analysis, see differences in the percentages shown in Tables 2-3. Notable differences for Professor attributes are higher expectations for Research Funding, Recognised Research, REF (Table 2), Leadership and Strategy (Table 3), but lower expectations regarding teaching Administration and LTAS/Frameworks (Table 3). 
Table 4. Pearson correlation coefficients $r$ between attributes of Lecturer vs. Senior Lecturer vs Professor adverts.

\begin{tabular}{llll}
\hline & Lec & SL & Prof \\
\hline (a) Job attributes & & $0.886^{* *}$ & $0.597^{*}$ \\
Lec & 1 & 1 & $0.638^{*}$ \\
SL & $0.886^{* *}$ & $0.638^{*}$ & 1 \\
Prof & $0.597^{*}$ & & $0.682^{*}$ \\
(b) Research attributes & 1 & $0.981^{* *}$ & $0.645^{*}$ \\
Lec & $0.981^{* *}$ & 1 & 1 \\
SL & $0.682^{* *}$ & $0.645^{*}$ & 0.146 \\
Prof & 1 & $0.987^{* *}$ & 0.227 \\
(c) Teaching attributes & $0.987^{* *}$ & 1 & 1 \\
Lec & 0.146 & 0.227 & \\
SL & & & \\
Prof & Notes: ${ }^{* *}$ Correlation is significant at the 0.01 level. ${ }^{*}$ Correlation is significant at the 0.05 level.
\end{tabular}

Table 5. Statistically significant associations between job attributes ${ }^{\mathrm{a}}$.

\begin{tabular}{|c|c|c|}
\hline Attribute & $\begin{array}{l}\text { Number of non- } \\
\text { independent attributes }\end{array}$ & Non-independent attributes \\
\hline PhD & 7 & $\begin{array}{c}\operatorname{RO}\left(\chi^{2}(1)=15.1, p=0.000, \varnothing=0.273\right), \operatorname{BM}\left(\chi^{2}(1)=17.0\right. \\
p=0.000, \varnothing=-0.290), \operatorname{PE}\left(\chi^{2}(1)=10.7, p=0.001, \varnothing=-0.230\right), \operatorname{SRF}\left(\chi^{2}(1)=10.9, p=0.001, \varnothing=\right. \\
0.232), \operatorname{PhDd}\left(\chi^{2}(1)=84.5, p=0.000, \varnothing=-0.647\right), \operatorname{TEd}\left(\chi^{2}(1)=4.8, p=0.029, \varnothing=-0.154\right), \operatorname{PEd} \\
\left(\chi^{2}(1)=6.8, p=0.009, \varnothing=0.183\right)\end{array}$ \\
\hline BM & 7 & $\begin{array}{c}\operatorname{PE}\left(\chi^{2}(1)=14.4, p=0.000, \varnothing=0.267\right), \operatorname{PhD}\left(\chi^{2}(1)=17.0, p=0.000, \varnothing=-0.290\right), \operatorname{PgCE}\left(\chi^{2}(1)=10.4,\right. \\
p=0.001, \varnothing=0.227), \text { FHEA }\left(\chi^{2}(1)=6.1, p=0.014, \varnothing=0.174\right), \operatorname{PhDd}\left(\chi^{2}(1)=12.4, p=0.000, \varnothing=\right. \\
0.248), \operatorname{PgCEd}\left(\chi^{2}(1)=4.7, p=0.031, \varnothing=0.152\right), \operatorname{TEd}\left(\chi^{2}(1)=6.8, p=0.009, \varnothing=0.183\right)\end{array}$ \\
\hline PgCEd & 6 & $\begin{array}{c}\operatorname{BM}\left(\chi^{2}(1)=4.7, p=0.031, \varnothing=0.152\right), \operatorname{PE}\left(\chi^{2}(1)=13.4, p=0.000, \varnothing=0.258\right), \operatorname{PgCE}\left(\chi^{2}(1)=22.1, p\right. \\
=0.000, \varnothing=-0.331), \operatorname{FHEA}\left(\chi^{2}(1)=22.1, p=0.000, \varnothing=-0.331\right), \operatorname{CHd}\left(\chi^{2}(1)=4.0, p=0.044, \varnothing=\right. \\
0.141), \operatorname{FHEAd}\left(\chi^{2}(1)=108, p=0.000, \varnothing=0.730\right)\end{array}$ \\
\hline PE & 5 & $\begin{array}{c}B M\left(\chi^{2}(1)=14.4, p=0.000, \varnothing=0.267\right), \operatorname{PhD}\left(\chi^{2}(1)=10.7, p=0.001, \varnothing=-0.230\right), \operatorname{PgCEd}\left(\chi^{2}(1)=\right. \\
13.4, p=0.000, \varnothing=0.258), \text { FHEAd }\left(\chi^{2}(1)=6.5\right. \\
p=0.011, \varnothing=0.180), \operatorname{PEd}\left(\chi^{2}(1)=28.6, p=0.000, \varnothing=-0.376\right)\end{array}$ \\
\hline FHEAd & 5 & $\begin{array}{c}\operatorname{PE}\left(\chi^{2}(1)=6.5, p=0.011, \varnothing=0.180\right), \operatorname{PgCE}\left(\chi^{2}(1)=17.3, p=0.000, \varnothing=-0.292\right), \text { FHEA }\left(\chi^{2}(1)=27.0,\right. \\
p=0.000, \varnothing=-0.365), \operatorname{CHd}\left(\chi^{2}(1)=5.4, p=0.020, \varnothing=0.163\right), \operatorname{PgCEd}\left(\chi^{2}(1)=108, p=0.000, \varnothing=\right.\end{array}$ \\
\hline TEd & 5 & $\begin{array}{l}0.730) \\
\operatorname{RO}\left(\chi^{2}(1)=6.3, p=0.012, \varnothing=-0.176\right), \operatorname{BM}\left(\chi^{2}(1)=6.8, p=0.009, \varnothing=0.183\right), \operatorname{TE}\left(\chi^{2}(1)=62.4, p=\right. \\
0.000, \varnothing=-0.556), \operatorname{PhD}\left(\chi^{2}(1)=4.8, p=0.029, \varnothing=-0.154\right), \operatorname{SRF}\left(\chi^{2}(1)=5.1, p=0.024, \varnothing=-0.159\right)\end{array}$ \\
\hline PgCE & 4 & $\begin{array}{c}B M\left(\chi^{2}(1)=10.4, p=0.001, \varnothing=0.227\right), \operatorname{FHEA}\left(\chi^{2}(1)=140.4, p=0.000, \varnothing=0.834\right), \operatorname{PgCEd}\left(\chi^{2}(1)=\right. \\
22.1, p=0.000, \varnothing=-0.331), \operatorname{FHEAd}\left(\chi^{2}(1)=17.3, p=0.000, \varnothing=-0.292\right)\end{array}$ \\
\hline FHEA & 4 & $\begin{aligned} \operatorname{BM}\left(\chi^{2}(1)=\right. & 6.1, p=0.014, \varnothing=0.174), \operatorname{PgCE}\left(\chi^{2}(1)=140.4, p=0.000, \varnothing=0.834\right), \operatorname{PgCEd}\left(\chi^{2}(1)=\right. \\
& 22.1, p=0.000, \varnothing=-0.331), \operatorname{FHEAd}\left(\chi^{2}(1)=27.0, p=0.000, \varnothing=-0.365\right)\end{aligned}$ \\
\hline PEd & 4 & $\begin{array}{c}\operatorname{PE}\left(\chi^{2}(1)=28.6, p=0.000, \varnothing=-0.376\right), \operatorname{PhD}\left(\chi^{2}(1)=6.8, p=0.009, \varnothing=0.183\right), C H\left(\chi^{2}(1)=4.8, p=\right. \\
0.028, \varnothing=-0.155), \operatorname{PhDd}\left(\chi^{2}(1)=5.5, p=0.019, \varnothing=-0.165\right)\end{array}$ \\
\hline SRF & 3 & $\begin{array}{c}R O\left(\chi^{2}(1)=16.5, p=0.000, \varnothing=0.286\right), \operatorname{PhD}\left(\chi^{2}(1)=10.9, p=0.001, \varnothing=0.232\right), \operatorname{TEd}\left(\chi^{2}(1)=5.1, p=\right. \\
0.024, \varnothing=-0.159)\end{array}$ \\
\hline PhDd & 3 & $\begin{aligned} & B M\left(\chi^{2}(1)=12.4, p=0.000, \varnothing=0.248\right), \operatorname{PhD}\left(\chi^{2}(1)=84.5, p=0.000, \varnothing=-0.647\right), \operatorname{PEd}\left(\chi^{2}(1)=5.5, p\right. \\
&=0.019, \varnothing=-0.165)\end{aligned}$ \\
\hline $\mathrm{CHd}$ & 3 & $\begin{array}{c}C H\left(\chi^{2}(1)=52.6, p=0.000, \varnothing=-0.510\right), \operatorname{PgCEd}\left(\chi^{2}(1)=4.0, p=0.044, \varnothing=0.141\right), \text { FHEAd }\left(\chi^{2}(1)=\right. \\
5.4, p=0.020, \varnothing=0.163)\end{array}$ \\
\hline RO & 2 & $\operatorname{PhD}\left(\chi^{2}(1)=15.1, p=0.000, \varnothing=0.273\right), \operatorname{SRF}\left(\chi^{2}(1)=16.5, p=0.000, \varnothing=0.286\right)$ \\
\hline $\mathrm{CH}$ & 2 & $\operatorname{CHd}\left(\chi^{2}(1)=52.6, p=0.000, \varnothing=-0.510\right), \operatorname{PEd}\left(\chi^{2}(1)=4.8, p=0.028, \varnothing=-0.155\right)$ \\
\hline TE & 1 & $\operatorname{TEd}\left(\chi^{2}(1)=62.4, p=0.000, \varnothing=-0.556\right)$ \\
\hline
\end{tabular}

a BM: BSc/BEng/MSc (essential): CH: Chartered (essential); CHd: Chartered (desirable); FHEA: FHEA (essential); FHEAd: FHEA (desirable); PE: Professional Experience (essential); PEd: Professional Experience (desirable); PgCE: PgCE (essential); PgCEd: PgCE (desirable); PhD: PhD (essential); PhDd: PhD (desirable); RO: Research Outputs; SRF: Securing Research Funding (desirable); TE: Teaching Experience (essential); TEd: Teaching Experience (desirable). 


\subsection{Statistically significant associations within job, research, and teaching attributes}

Tables 5-7 show the statistically significant associations within job, research and teaching attributes in ranking order (from highest to lowest number of non-independent attributes). These tables present the key ranking data on the left and more detailed statistical data on the right in line with how data is presented for this specific test and also for others for possible comparative or replicative purposes. Chi-square independence test results $\left(\chi^{2}\right.$ and $\left.p\right)$ and the phi coefficient $(\varnothing)$ are given for each non-independent attribute listed in these tables (italic: $p<0.01$; non-italic: $p<0.05$ ). Table 5 shows a high number of associations between many of these job attributes. The only attributes with a strong association (i.e $\varnothing>0.7$, excluding essential vs. desirable of the same attribute) are PgCE with FHEA $(\varnothing=0.834)$ and PgCEd with FHEAd $(\varnothing=0.730)$, meaning that, for example, adverts mentioning a PgCE are highly likely to also mention FHEA. Non-independent attributes with lower phi coefficient values (e.g. $\varnothing<0.4$ ) are still associated, but the associations are weaker. Particularly striking is the lack of any statistical association with Teaching Experience, which could be determined as adverts being 'biased' towards research-based attributes with a lack of focus on what could arguably be more important from a student perspective, i.e. teaching-related. Indeed, any shift towards TEF and the ever-increasing focus on National Student Satisfaction Survey (NSS) remains imperceptible, with associations between the teaching-related deemed inconsequential. Drawing on the statistical evidence presented, teaching experience is not paramount when advertising certain 'academic job roles'.

Table 6 for research attributes below shows, similarly as with job attributes, there are a high number of associations (although none are strong, as $\varnothing<0.5$ for all attributes). This is perhaps to be expected, as research publications tend to follow successful completion of a PhD, and a successful PhD may result in research funding being applied for and being awarded, and publications $3^{*}$ to $4^{*}$ standard for the UK REF exercise resulting in submission to the REF. As with previous results, this data appears to exclude the industrial-based practitioner from applying, who it could be argued possesses little or none of these research attributes.

Table 6. Statistically significant associations between research based attributes ${ }^{a}$.

\begin{tabular}{|c|c|c|}
\hline Attribute & $\begin{array}{c}\text { Number of non- } \\
\text { independent attributes }\end{array}$ & Non-independent attributes \\
\hline REF & 8 & $\begin{array}{c}\boldsymbol{R F}\left(\chi^{2}(1)=12.6, p=0.000, \varnothing=0.250\right), \mathbf{J P Q}\left(\chi^{2}(1)=3.9, p=0.047,\right. \\
\varnothing=0.140), \operatorname{PhDS}\left(\chi^{2}(1)=5.1, p=0.024, \varnothing=0.159\right), \boldsymbol{R R}\left(\chi^{2}(1)=12.3, p=0.000, \varnothing=0.247\right), \boldsymbol{I P} \\
\left(\chi^{2}(1)=11.3, p=0.001, \varnothing=0.236\right), \operatorname{MDR}\left(\chi^{2}(1)=10.2, p=0.001, \varnothing=0.225\right), \operatorname{CLT}\left(\chi^{2}(1)=8.5, p\right. \\
=0.003, \varnothing=0.206), \operatorname{RS}\left(\chi^{2}(1)=4.2, p=0.040, \varnothing=0.144\right)\end{array}$ \\
\hline RR & 7 & $\begin{array}{c}\operatorname{CR}\left(\chi^{2}(1)=5.1, p=0.023, \varnothing=0.16\right), \operatorname{RF}\left(\chi^{2}(1)=21.1, p=0.000, \varnothing=0.323\right), J P Q\left(\chi^{2}(1)=24.3, p\right. \\
=0.000, \varnothing=0.347), \operatorname{PhDS}\left(\chi^{2}(1)=5.0, p=0.025, \varnothing=0.158\right), \operatorname{REF}\left(\chi^{2}(1)=12.3, p=0.000, \varnothing=\right. \\
0.247), \operatorname{IP}\left(\chi^{2}(1)=14.0, p=0.000, \varnothing=0.263\right), \operatorname{CLT}\left(\chi^{2}(1)=4.7, p=0.030, \varnothing=0.152\right)\end{array}$ \\
\hline RF & 6 & $\begin{array}{c}C R\left(\chi^{2}(1)=7.6, p=0.006, \varnothing=0.194\right), J P Q\left(\chi^{2}(1)=25.0, p=0.000, \varnothing=0.352\right), \operatorname{PhDS}\left(\chi^{2}(1)=\right. \\
12.7, p=0.000, \varnothing=0.251), R R\left(\chi^{2}(1)=21.1, p=0.000, \varnothing=0.323\right), \operatorname{REF}\left(\chi^{2}(1)=12.6, p=0.000,\right. \\
\varnothing=0.250), \operatorname{MDR}\left(\chi^{2}(1)=7.2, p=0.007, \varnothing=0.189\right)\end{array}$ \\
\hline PhDS & 6 & $\begin{array}{c}\operatorname{RF}\left(\chi^{2}(1)=12.7, p=0.000, \varnothing=0.251\right), J P Q\left(\chi^{2}(1)=11.6, p=0.001, \varnothing=0.240\right), \operatorname{RR}\left(\chi^{2}(1)=5.0\right. \\
p=0.025, \varnothing=0.158), \operatorname{REF}\left(\chi^{2}(1)=5.1, p=0.024, \varnothing=0.159\right), \operatorname{IP}\left(\chi^{2}(1)=7.06, p=0.008, \varnothing=\right. \\
0.187), \operatorname{MDR}\left(\chi^{2}(1)=5.6, p=0.018, \varnothing=0.166\right)\end{array}$ \\
\hline CR & 5 & $\begin{array}{c}\operatorname{RF}\left(\chi^{2}(1)=7.6, p=0.006, \varnothing=0.194\right), \operatorname{JPQ}\left(\chi^{2}(1)=9.4, p=0.02, \varnothing=0.215\right), \operatorname{RR}\left(\chi^{2}(1)=5.1, p=\right. \\
0.023, \varnothing=0.16), \operatorname{CLT}\left(\chi^{2}(1)=19.8, p=0.000, \varnothing=-0.313\right), \operatorname{RS}\left(\chi^{2}(1)=9.8, p=0.002, \varnothing=-0.220\right)\end{array}$ \\
\hline JPQ & 5 & $\begin{array}{c}\operatorname{RF}\left(\chi^{2}(1)=25.0, p=0.000, \varnothing=0.352\right), \operatorname{PhDS}\left(\chi^{2}(1)=11.6, p=0.001, \varnothing=0.240\right), \operatorname{RR}\left(\chi^{2}(1)=\right. \\
24.3, p=0.000, \varnothing=0.347), \operatorname{REF}\left(\chi^{2}(1)=3.9, p=0.047, \varnothing=0.140\right), \operatorname{MDR}\left(\chi^{2}(1)=10.7, p=\right. \\
0.001, \varnothing=0.231)\end{array}$ \\
\hline CLT & 5 & $\begin{array}{c}C R\left(\chi^{2}(1)=19.8, p=0.000, \varnothing=-0.313\right), \operatorname{RR}\left(\chi^{2}(1)=4.7, p=0.030, \varnothing=0.152\right), \operatorname{REF}\left(\chi^{2}(1)=8.5\right. \\
p=0.003, \varnothing=0.206), \operatorname{IP}\left(\chi^{2}(1)=5.7, p=0.017, \varnothing=0.168\right), \operatorname{RS}\left(\chi^{2}(1)=42.9, p=0.000, \varnothing=\right. \\
0.461)\end{array}$ \\
\hline IP & 4 & $\begin{aligned} & \operatorname{PhDS}\left(\chi^{2}(1)=7.1, p\right.=0.008, \varnothing=0.187), \operatorname{RR}\left(\chi^{2}(1)=14.0, p=0.000, \varnothing=0.263\right), \operatorname{REF}\left(\chi^{2}(1)=\right. \\
&11.3, p=0.001, \varnothing=0.236), \operatorname{CLT}\left(\chi^{2}(1)=5.7, p=0.017, \varnothing=0.168\right)\end{aligned}$ \\
\hline MDR & 4 & $\begin{array}{c}\boldsymbol{R F}\left(\chi^{2}(1)=7.2, p=0.007, \varnothing=0.189\right), J P Q\left(\chi^{2}(1)=10.7, p=0.001, \varnothing=0.231\right), \operatorname{PhDS}\left(\chi^{2}(1)=\right. \\
5.6, p=0.018, \varnothing=0.166), \operatorname{REF}\left(\chi^{2}(1)=10.2, p=0.001, \varnothing=0.225\right)\end{array}$ \\
\hline RS & 3 & $\begin{aligned} & C R\left(\chi^{2}(1)=9.8, p=0.002, \varnothing=-0.220\right), \operatorname{REF}\left(\chi^{2}(1)\right.=4.2, p=0.040, \varnothing=0.144), \operatorname{CLT}\left(\chi^{2}(1)=42.9,\right. \\
&p=0.000, \varnothing=0.461)\end{aligned}$ \\
\hline
\end{tabular}

a CLT: Culture; CR: Contribute to Research; IP: International Profile; JPQ: Journals / Publications / Quality outputs; MDR: Multi-Disciplinary Research; PhDS: PhD Supervision; REF: Research Excellence Framework; RF: Research Funding; RR: Recognised Research; RS: Research Strategy. 
Table 7. Statistically significant associations between teaching attributes ${ }^{\mathrm{a}}$.

\begin{tabular}{ccc}
\hline Attribute & $\begin{array}{c}\text { Number of non- } \\
\text { independent attributes }\end{array}$ & Non-independent attributes \\
\hline CUR & 2 & $\operatorname{AD}\left(\chi^{2}(1)=14.7, p=0.000, \varnothing=0.269\right), E I\left(\chi^{2}(1)=14.3, p=0.000, \varnothing=-0.267\right)$ \\
AD & 1 & $\operatorname{CUR}\left(\chi^{2}(1)=14.7, p=0.000, \varnothing=0.269\right)$ \\
EI & 1 & $\operatorname{CUR}\left(\chi^{2}(1)=14.3, p=0.000, \varnothing=-0.267\right)$ \\
LD & 1 & $\operatorname{ST}\left(\chi^{2}(1)=5.6, p=0.018, \varnothing=0.166\right)$ \\
ST & 1 & LD $\left(\chi^{2}(1)=5.6, p=0.018, \varnothing=0.166\right)$ \\
LF & 0 & - \\
VLES & 0 & - \\
PD & 0 & - \\
ISM & 0 &
\end{tabular}

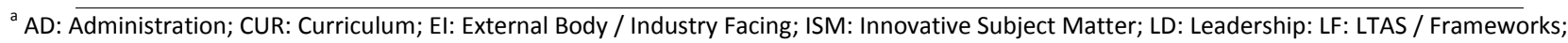
VLEs; PD: Pedagogic Development; ST: Strategic.

Notably, and in contrast to the many associations shown in Tables 5 and 6, in Table 7 there are very few associations between teaching-related attributes, and these are all weak $(\varnothing<0.3)$.

If Tables 5-7 are considered collectively, the key finding is that there are several relationships between job attributes, and between research attributes, but very few relationships between teaching attributes. These statistical results indicate that research attributes are well defined and interrelated, whilst teaching attributes tend to be independent and variable across the job adverts. The REF is an over-arching attribute that 'connects' many of the other research-based attributes (see Table 6), whilst there is no over-arching attribute in teaching adverts. Most teaching attributes, it could be argued, are 'stand-alone', i.e. independent. The striking example is 'Teaching Experience' at the bottom of Table 5.

\subsection{Analysis of pre-TEF and post-TEF advertisements}

In Tables 8-10, data is presented in ranking order, from highest to lowest overall percentage. The sample size of adverts analysed was 96 pre-TEF ( $\mathrm{Lec}=52, \mathrm{SL}=39$, Prof $=5)$ and 106 post-TEF $(\mathrm{Lec}=68, \mathrm{SL}=31, \mathrm{Prof}=7)$. A comparison of pre-TEF vs. post-TEF results for Tables 8-10 shows little variation in attributes' rankings. A Pearson correlation test shows a strong and statistically significant correlation of job attributes pre-TEF vs. post-TEF ( $r=0.899$, $p=0.000)$. Thus, there is very little change between pre and post-TEF job adverts, and therefore the priority remains with research; not teaching.

Table 8. Percentages of job attributes appearing in academic adverts, pre-TEF and post -TEF.

\begin{tabular}{|c|c|c|c|c|c|}
\hline \multicolumn{2}{|c|}{ Ranking } & \multirow{2}{*}{ Attribute } & \multirow{2}{*}{ Essential vs. Desirable } & \multicolumn{2}{|c|}{ Overall (\%) } \\
\hline Pre-TEF & Post-TEF & & & Pre-TEF & Post-TEF \\
\hline 1 & 2 & BSc / BEng / MSc & Essential (qualifications) & 83.3 & 64.2 \\
\hline 2 & 1 & Research Outputs & Desirable & 65.6 & 81.1 \\
\hline 3 & 3 & Professional Experience & Essential (experience) & 64.6 & 63.2 \\
\hline 4 & 5 & Teaching Experience & Essential (experience) & 63.5 & 61.3 \\
\hline 5 & 4 & $\mathrm{PhD}$ & Essential (qualifications) & 61.5 & 62.3 \\
\hline 6 & 7 & PgCE & Desirable & 42.7 & 37.7 \\
\hline 7 & 7 & Chartered & Essential (qualifications) & 39.6 & 40.6 \\
\hline 7 & 10 & Chartered & Desirable & 39.6 & 33.0 \\
\hline 8 & 9 & FHEA & Desirable & 36.5 & 35.8 \\
\hline 9 & 6 & Securing Research Funding & Desirable & 33.3 & 54.7 \\
\hline 10 & 12 & $\mathrm{PhD}$ & Desirable & 22.9 & 27.4 \\
\hline 11 & 13 & FHEA & Essential (qualifications) & 20.8 & 25.5 \\
\hline 12 & 14 & Teaching Experience & Desirable & 21.9 & 21.7 \\
\hline 13 & 11 & $\mathrm{PgCE}$ & Essential (qualifications) & 17.7 & 28.3 \\
\hline 14 & 15 & Professional Experience & Desirable & 9.4 & 5.7 \\
\hline
\end{tabular}


Similarly, there is a strong and statistically significant correlation of research attributes pre-TEF vs. post-TEF ( $r=$ $0.980, p=0.000)$. Here again, the correlation is even higher, showing hardly any difference between research attributes in the job adverts pre and post TEF.

Table 9. Percentages of research attributes appearing in academic adverts, pre-TEF and post-TEF.

\begin{tabular}{cclcc}
\hline \multicolumn{2}{c}{ Ranking } & Attribute & \multicolumn{2}{c}{ Overall (\%) } \\
Pre-TEF & Post-TEF & & Pre-TEF & Post-TEF \\
\hline 1 & 1 & Contribute to Research & 87.5 & 90.6 \\
2 & 3 & Research Funding & 60.4 & 50.0 \\
3 & 2 & Journals / Publications / Quality outputs & 56.3 & 50.9 \\
4 & 4 & PhD Supervision & 50.0 & 48.1 \\
5 & 5 & Recognised Research & 36.5 & 44.3 \\
6 & 6 & REF & 20.8 & 18.9 \\
7 & 7 & International Profile & 15.6 & 15.1 \\
8 & 7 & Multi-Disciplinary Research & 6.3 & 15.1 \\
9 & 8 & Culture & 4.2 & 1.9 \\
10 & 9 & Research Strategy & 2.1 & 0.9 \\
\hline
\end{tabular}

The correlation of teaching attributes pre-TEF vs. post-TEF is also strong and statistically significant $(r=0.928, p=$ 0.000). Here again there is strikingly little difference between the adverts pre and post-TEF.

Taken together, the results of Tables 8-10 indicate the focus and direction of adverts have not changed post TEF. This is demonstrated by the very high correlation coefficients $(r \geq 0.9)$ found for job attributes, research attributes and teaching attributes pre-TEF vs. post-TEF, and the very high level of statistical significance of the results $(p=0.000)$.

Table 10. Percentages of teaching attributes appearing in academic adverts, pre-TEF and post-TEF.

\begin{tabular}{cclcc}
\hline \multicolumn{2}{c}{ Ranking } & Attribute & \multicolumn{2}{c}{ Overall (\%) } \\
Pre-TEF & Post-TEF & & Pre-TEF & Post-TEF \\
\hline 1 & 2 & Administration & 82.3 & 72.6 \\
2 & 3 & Curriculum & 74.0 & 60.4 \\
3 & 1 & LTAS / Frameworks & 62.5 & 79.2 \\
4 & 4 & External Body / Industry Facing & 40.6 & 41.5 \\
5 & 6 & VLEs & 28.1 & 23.6 \\
6 & 7 & Pedagogic Development & 22.9 & 12.3 \\
7 & 5 & Leadership & 19.8 & 34.0 \\
8 & 8 & Innovative Subject Matter & 10.4 & 9.4 \\
9 & 10 & Strategic & 7.3 & 7.5 \\
\hline
\end{tabular}

\section{Discussion}

Research findings disclose numerous discussion points; however, two investigative highlights dominate. First, research attributes across all job advertisements demonstrate a statistically significant association and an unmistakable homogeneity. In stark contrast, teaching attributes across all job advertisements disclose virtually no significant associations. Second, job advertisements demonstrate imperceptible changes post-TEF when compared with pre-TEF. The results would imply those responsible for writing advertisements exhibit a clear understanding of the phraseology to adopt in connection with key research attributes. Conversely, in relation to teaching attributes, there is a striking heterogeneity. This could suggest that either teaching phraseology has yet to become institutionalised, or alternatively there remains limited understanding of what employability attributes would constitute a homogeneous set of performance criteria for teaching excellence in C\&E education. Indeed, the heterogeneity exhibited in C\&E adverts in relation to teaching criteria may translate more generally across academic disciplines ( $O$ 'Leary, Cui, and French 2019). Given the striking similarity for adverts pre-TEF and post-TEF, it is probability the latter. The lack of a coherent employability framework for teaching is all the more surprising given the availability of generic (Cashmore, Cane, and Cane 2013; Advance HE 2018, 2019; McHanwell and Robson 2018) and engineering specific guidance (Graham 2016, 2018) that could be adopted to assist those responsible for formulating job adverts.

The disconnect between the job adverts, teaching excellence and desired attributes is reinforced, with teaching 'administration' ranking highest. This compares to 'innovative subject matter' positioned near the bottom. Yet to aspire for excellence in teaching, it may be anticipated the significance of 'administration' and 'innovative teaching 
matter' attributes would be reversed, and that there would a greater role for Sotl and professional and industry experience to encourage a linking of theory and practice in the classroom. Indeed, as stakeholders in $\mathrm{HE}$, students are known to value real word examples (Collins and Davies 2009; Tennant et al. 2015; Forster et al. 2017; Pilcher et al. 2017); inspirational teaching methods (Sue and Wood 2012): and that staff have received training in how to teach and possess professional / industry expertise (Buckley, Soilemetzidis, and Hillman 2015). Whilst the majority of HE academic staff are expected to complete a Postgraduate Certificate in Education (Gosling 2010; Cui, French, and O'Leary 2019), such training cannot give them key professional / industry experience. This demonstrates the increasing importance of teaching 'administration' over 'teaching' itself. The drift towards organisational efficacy at the expense of teaching proficiency is indicative of the general increase in the power of administration and administrative roles (Ginsberg 2011) and by extension HE governance in the UK (Erickson, Hanna, and Walker 2020).

The lack of any substantive adjustment pre-TEF and post-TEF could indicate many factors. Perhaps TEF has not yet influenced job advertisements during the timeframe of our sampling. This would be extraordinary given the knowledge and discussion of TEF in the public domain. Indeed institutions had already undergone TEF metrics and performance audits (Gold, Silver, and Bronze) by the time many of the adverts were sampled and recent Department of Education research (Vivian et al. 2019) claim evidence it has impacted upon recruitment. Yet, the results here show that the TEF has simply failed to redress university employment bias. History suggests research bias was customary in UK HEl's (Robbins 1963) well before the RAE, REF and TEF. However, Macfarlane's (2015, np) overview of early volumes of Studies in Higher Education from the mid-1970s revealed that 'many articles focused on undergraduate teaching - the language of this time was all about "university teachers"' (his emphasis). The introduction of RAE in 1986 could be viewed as a catalyst for a progressive shift in HEl culture. This has been enacted through an ontological and epistemological 'signalling' in job adverts as to what would be considered a stereotypical role identity for academics, being that of teaching-research-administration. The prioritisation of funding towards research would automatically relegate teaching and afford preference to research and administration. Despite the rhetoric of 'parity of esteem with research' emanating from HEl's, teaching continues to lack both institutional power and professional prestige. This in turn begins to question the whole aim or idea of what higher education is and who and what is it for? Is higher education's role one of following government policy to focus almost solely on research now to the detriment of teaching? Critically, has this changed the nature and focus of higher education institutions from a previous technical and professional focus (particularly in the case of the former polytechnic post-92 institutions) to a focus on income generation through seeking research grants and publications? Reference to Elton's $(2009,137)$ analysis of Wilhelm von Humboldt's memorandum for the new University of Berlin in the early 1800s provides some insight to such questions: 'it was Humboldt who realized that a university that had no other objectives than to serve the short-term objectives of the state would fail both the state and as a university.'

Indeed, in addition to the two research highlights outlined, one key job criterion merits further scrutiny in this context. The widespread practice of classifying a PhD as 'essential' and 'professional experience' as desirable endorses the research first narrative. The likelihood of an industry applicant holding a PhD and demonstrating professional experience could be considered atypical. Whilst adroitly framed, the demand for a PhD (also noted in the USA by Schuster and Finkelstein 2006) deliberately champions Career Academics whilst simultaneously disadvantaging applicants who may satisfy other key attributes requested within the job adverts. Indeed an allied point is the significant bias towards Professorial appointments having research credentials whilst not requiring teaching attributes. The lack of importance given to key teaching attributes at a senior academic level would appear consistent with entry-level academic staff. This finding is similar to Nuttall et al. $(2013,336)$ who found that job adverts for teacher educators in Australia, 'did not specify the skills of a 'gifted teacher' but sought instead 'quality researchers'.' In short, research attributes dominate corporate decision-making and continue to dictate the HEI recruitment policy and procedure, and may be changing the very nature and ethos of what higher education is about.

Furthermore, although the focus here has been on key research and teaching attributes identified in job adverts, it is also worth highlighting key employment criteria that receive scant prominence. Despite the rhetoric of academicindustry partnerships, very little onus is placed on professional accreditation or teaching qualifications. Indeed, the picture these advertisements present is of a growing cohort of faculty staff academically qualified and best placed to secure research income, but who possess limited industrial experience of the sector or professional context for which their students are destined. Again, the impact and reach of TEF appear negligible.

Whilst our sample consists of mainly traditional academic posts requiring candidates to engage in teaching and research, there has been a growth of new teaching only appointments within UK HEI's. This has been accompanied by an increase in existing academics being transferred off the REF, with a sideways redeployment to teaching-only contracts (Baker 2019). The reorganisation and subsequent categorisation of academic staff as either teaching fellow (research inactive) and lecturer (research active) is driven by economic motives (Power, 2015) and the desire of enhancing an HEl's submission to REF 2021. Indeed, some HEl's have redefined the research inactive/active description further by classifying academic/lecturing staff with $10 \%$ or less research activity on their annual activity plans as not having significant responsibility for research (SRR). Consequently, lecturing staff not meeting the overly prescriptive criteria ( $>10 \%$ ) for SRR as opposed to a research performance-based criteria and output are therefore not 
eligible for submission to the REF 2021. This is of importance to our findings as it demonstrates the institutional power and reach of research gatekeepers and helps clarify why the role of teaching in HEI's remains so impoverished within the job adverts reviewed.

Whilst teaching fellow career pathways display rhetorical parity (vis-à-vis opportunities for Professorial Teaching Fellows) with peers employed on teaching and research contracts there appears to be a paradoxical outcome. Despite a growth in the number of academics securing professional accreditation with the Higher Education Academy vis-à-vis the HEA Fellowship (Advance 2018) and a longstanding annual National Teaching Fellowship Scheme to recognise and award best practice (Advance 2019) there remains little evidence to suggest that HEl's have prioritised teaching and learning in the recruitment process (nor, as noted above, in relation to criteria for promotion for research and teaching routes). As this study discloses, there was scant evidence of requirements for candidates to demonstrate knowledge or ambition to engage in Scholarship of Teaching and Learning (Sotl). Furthermore, whilst the European University Association (Dakovic and Loukkaola 2017) recommend HEl's provide funding for academics to professionalise their teaching through Action Research / Pedagogical Research, serious barriers exist for subsequent dissemination of findings in publications.

Firstly, in the UK the REF has distorted the value of the Scholarship of Teaching and Learning (Sotl) through considering those academics employed on teaching-only contracts or academic staff identified as having no significant responsibility for research (SSR) to be 'research inactive' and thus, being engaged in non-disciplinary research is stigmatised. Secondly, challenging this position through seeking inclusion in a REF submission is beset by institutional gatekeepers (Cotton, Miller, and Kneale 2017; Tierney 2019) who may ignore HE pedagogy research from colleagues outside an education department and focus on, e.g. primary or secondary education research (Kneale, Cotton, and Miller 2016). A further irony has come to the fore in preparation for REF 2021, for the first time the impact of research on teaching and learning practice will be accepted as evidence of 'impact': 'Impacts on students, teaching or other activities both within and/or beyond the submitting HEI are included' (REF 2019, 68).

Whether this development can quell the research - teaching nexus doubters (Kinchin and Hay 2007) remains unknown. Suffice to say, the inclusion of impacts on students in the forthcoming REF is tantamount to a continuing focus on 'what students learn' to an exclusion of considering 'how students learn'. This approach continues to undermine and diminishes the kudos of academics who seek to engage in the Scholarship of Teaching and Learning (Sotl) and derive an occupational identity, esteem and pride through their work. Critically, it means that the drive and identity of higher education is one that rewards and extols the virtues of research but not of teaching or of professional and industry experience. If this is not surprising given historical government policy prioritisation of research, the introduction of the TEF, despite its rhetoric to recalibrate the focus towards teaching has not yet translated into reality.

\section{Conclusion}

This paper has presented and analysed data from a large sample of job adverts including 'Lecturer', 'Senior Lecturer' and 'Professor' roles in C\&E (Construction \& Engineering) for periods both prior to the recent introduction of the Teaching Excellence Framework to the UK Higher Education System (pre-TEF) and for after its introduction (post-TEF). This was done in order to identify if there has been any change in response to what is a key government policy initiative for HEl's in the UK. The correlations between the key attributes in these adverts were examined for (1) overall roles, (2) for 'research', and (3) for 'teaching'. Furthermore, correlations also captured job adverts for both preTEF and post TEF periods. As such this research contributes to the existing body of research into job advertisements and their role in presenting policy in HEls, and, specifically does so in the field of C\&E and in the context of the introduction of the TEF.

Analysis demonstrates two key findings. Firstly, whilst HEl's display homogeneity in relation to the phraseology for 'research' attributes and disclose positive correlations across key research attributes, the contrast in relation to 'teaching' is stark. Indeed, the correlation for teaching attributes is so indeterminate as to imply a haphazard approach to the vocabulary and collocations used by HEl's in their recruitment. The lack of a consistent and coherent approach to key teaching attributes is compounded by the identification of 'administration' as the key teaching priority. Compared to key attributes such as 'innovative teaching material' or industry experience, this would suggest that academics who prioritise teaching are regarded primarily as administrators rather than educators. This is idiosyncratic and as Lewis (2007, p.101) has argued - 'teaching should be a serious component of the faculty hiring criteria, not simply a peripheral item.'

Secondly and significantly, there appears to be limited difference in attribute priorities pre- and post-TEF. Future research could consider whether similar patterns are replicated in other subject areas and investigate further to see if any correlations appear in relation to job advertisements and the specific type of institution studied (e.g. Post-92 or Russell Group type institutions such as the University of Oxford or the University of Cambridge). In addition, although the adverts analysed here are for institutions that employ and recruit globally, and in many cases have campuses worldwide, they are UK-based institutions. In addition, studying whether such patterns are reflected in education systems elsewhere would add to the rich picture presented. 
The central message from the findings is the continued institutionalised culture of research policy and recruitment practice in UK HEI's. This is at odds with the recommendations of Dearing (1997) and subsequent efforts to professionalise the role of teaching in UK universities vis-à-vis a plethora of initiatives from the Higher Education Academy (HEA) and the establishment of a UK Professional Standards Framework (UKPSF).

Not only are institutions continuing to recruit for C\&E with a clearly identifiable focus on research, but this policy comes at the expense of a consistent, coherent and clear commitment to achieving teaching excellence (cf. Gretton and Raine 2017) or the importance of industry experience. Not only this, but institutions appear to have a clear understanding of, and a compelling ability to emulate, government policy on research, as demonstrated by the positive correlations between key attributes advertised for in relation to 'research'. Conversely, however, institutions appear to have almost no understanding of what to advertise in relation to teaching. The default position is to recruit new academics who can demonstrate potential eligibility for submission to REF 2021 and beyond. This may be because institutions have little understanding of what teaching is, as shown in both the extremely low to almost zero correlations between the key attributes used to advertise for 'teaching', and also perhaps reinforced by the high priority accorded to 'administration' in these teaching attributes, something which resonates with approaches to promotion also (cf. Ginsberg 2011).

Arguably, this underlying lack of understanding may actually be because the message conveyed by the UK government with regard to teaching, and to TEF, remains confused and vague. This is despite close to a billion pounds allocated to support the enhancement of teaching quality in the UK since 1998 (Kernohan 2014). Perhaps the identification of what constitutes excellence in teaching remains far more elusive than what constitutes excellence in research. This is suggested by ongoing debates about TEF and teaching, by the similarity of adverts pre-TEF and post$\mathrm{TEF}$, and also by the fact that institutions have managed to understand and emulate what is wanted in relation to 'research'. Is it therefore possible that institutions are being measured by that which eludes measurement, and, perhaps more worryingly, is something that it is not appropriate to measure in terms of performance metrics?

\section{Notes}

1. We note that in the UK there have been recent moves by many HE institutions to adopt US terminology for roles (e.g. associate professor instead of senior lecturer) and thus at this time of transition such titles are used interchangeably or in tandem by institutions. We note this here but for ease of reading we use the former terms of lecturer, senior lecturer and professor subsequently in the paper.

2. Here 'Administration' is considered under teaching attributes because this is how it appeared in the job attributes; we interpret the term 'administration' to relate to those administrative tasks related to the activity of teaching such as organising materials for online platforms, formatting examinations, as well as responsibilities such as being year coordinators, membership of committees and dealing with admissions.

\section{Disclosure statement}

No potential conflict of interest was reported by the author(s).

\section{Notes on contributors}

Nick Pilcher is a lecturer in The Business School at Edinburgh Napier University. He is the Programme leader for the M.Sc. in intercultural Business Communication and teaches academic writing in subjects. His research interests centre around education, language and qualitative research methods. He has published and contributed to work published in journals such as Qualitative Research, Psychology of Music, the International Journal of Qualitative Studies in Education and the International Journal of Shipping and Transport Logistics.

Laurent Galbrun is an Assistant Professor in Acoustics in the School of Energy, Geoscience, Infrastructure and Society, Heriot-Watt University, Edinburgh (UK). His expertise covers the fields of building acoustics, environmental noise and soundscapes. He is Programme Director for the Graduate Apprenticeship in Civil Engineering at Heriot-Watt University. Professionally, he is a Member of the Institute of Acoustics (MIOA) and of the Acoustical Society of America (MASA), as well as a Fellow of the Higher Education Academy (FHEA). He has won several teaching and learning prizes, including the Heriot-Wat University Graduate's Teaching Award in 2013 and 2017.

Nigel Craig is a Senior Lecturer and Programme Leader in Construction Management in the School of Engineering and Built Environment at Glasgow Caledonian University. Teaching interests include construction technology, construction process management, construction engineering and research methodology. Research interests focus on quality, cost/ finance, IT, plagiarism and building surveying. He has published in journals such as Structural Survey: Building Pathology, International Journal of Housing Markets and Analysis and Records Management.

Mike Murray is a teaching fellow in the Department of Civil \& Environmental Engineering at the University of Strathclyde. Mike is a Fellow of the Higher Education Academy and was awarded best Teacher in the Faculty of Engineering (2014) and Most Innovative University Teacher (2018) at the University Teaching Excellence Awards. He has contributed to work in journals such as Teaching in Higher Education, Higher Education Pedagogies, and Industry and Higher Education.

Alan Forster is Associate Professor in the School of Energy, Geoscience, Infrastructure and Society at Heriot-Watt University. He is the programme leader for the M.Sc. in Building Conservation and has 10 years industrial experience in Building Surveying and building conservation practice. His research investigates traditional and low-carbon building materials; building resilience to climate change; building conservation; and building survey and HBIM. He has published extensively and has attained research grants from major funding councils, including, EPSRC, RAE, RSE \& Innovate UK. Professionally, he is a Fellow of the Chartered Institute of 
Builders (FCIOB), the Chartered Association of Building Engineers (FCABE), the Higher Education Academy (FHEA) and is also a full member of the Institute of Historic Building Conservation (IHBC). He has won several teaching and learning prizes, including the Heriot-Watt University Graduate's Teaching Award in 2010.

Stuart Tennant is a lecturer in the School of Computing, Engineering and Physical Sciences at the University of the West of Scotland. He is a member of the Chartered Institute of Building (MCIOB) and Senior Fellow of the Higher Education Academy (SFHEA) Teaching interests include, project management, construction management, construction technology and industrial workplace learning. Research interests focus on construction supply chain management, procurement, team working in the built environment and educational studies. Stuart has published in journals such as Building Research \& Information (BRI), Construction Management and Economics (CME) and Teaching in Higher Education.

\section{ORCID}

Nick Pilcher http://orcid.org/0000-0002-5093-9345

Laurent Galbrun http://orcid.org/0000-0001-6152-8405

Nigel Craig http://orcid.org/0000-0002-3903-2785

Mike Murray http://orcid.org/0000-0002-7465-4870

Alan M. Forster http://orcid.org/0000-0001-6425-653X

Stuart Tennant http://orcid.org/0000-0001-9359-5717

\section{References}

Advance, H. E. 2018. "HEA Fellowship." Accessed August 2019. https://www.heacademy.ac.uk/individuals/fellowship.

Advance, H. E. 2019. "National teaching Fellowship." August 2019. https://www.advance-he.ac.uk/awards/teachingexcellenceawards/national-teaching-fellowship.

Baker, S. 2019. "UK Universities Shift to Teaching-Only Contracts Ahead of REF." Time Higher Education. Accessed May 2019. https://www.timeshighereducation.com/news/uk-universities-shift-teaching-only-contracts-ahead-ref.

Beach, A. L. 2016. "Boyer's Impact on Faculty Development." In Scholarship Reconsidered: Priorities of the Professoriate, edited by E. L. Boyer, Drew Moser, Todd C. Ream, and John M. Braxton, Expanded Edition, 13-18. San Francisco, CA: Jossey-Bass.

Becher, T. 1989. Academic Tribes and Territories: Intellectual Enquiry and the Cultures of Disciplines. Milton Keynes: Society for Research into Higher Education.

Bell, A. R., and C. Brooks. 2019. "Is There a 'Magic Link'between Research Activity, Professional Teaching Qualifications and Student Satisfaction?" Higher Education Policy 32 (2): 227-248. doi:10.1057/s41307-018-0081-0.

Bettinger, P., and M. Merry. 2018. "Follow-up Study of the Importance of Mapping Technology Knowledge and Skills for Entry-Level Forestry Jobs Positions, as Deduced From Recent job Advertisements." Mathematical and Computational Forestry \& NaturalResource Sciences 10 (1): 15-23. ISSN 1946-7664.

BIS. 2016. Success as a Knowledge Economy: Teaching Excellence, Social Mobility and Student Choice. London: Crown.

Blackmore, P., R. Blackwell, and M. Edmondson. 2016. Tackling Wicked Issues: Prestige and Employment. Outcomes in the Teaching Excellence Framework. Oxford: Higher Education Policy Institute.

Boyer, E. 1990. Scholarship Reconsidered: Priorities of the Professoriate. San Francisco, CA: Jossey-Bass.

Buckley, A., I. Soilemetzidis, and N. Hillman. 2015. The 2015 Student Academic Experience Survey. Accessed March 2019. https://www.hepi.ac.uk/wp-content/uploads/2015/06/AS-PRINTED-HEA HEPI report print4.pdf.

Burgan, M. 2006. What Ever Happened to the Faculty?: Drift and Decision in Higher Education. Baltimore, MD: Johns Hopkins University.

Calhoun, C. 2014. "Conclusion: The Robbins Report and British Higher Education Past \& Future." In Shaping Higher Education: 50 Years After Robbins, edited by Nicholas Barr, 65-86. London: The London School of Economics and Political Science.

Cashmore, A., C. Cane, and R. Cane. 2013. "Rebalancing Promotion in the HE sector: Is Teaching Excellence Being Rewarded?" Higher Education Academy. https://www.heacademy.ac.uk/knowledge-hub/rebalancing-promotion-hesector-teachingexcellence-being-rewarded.

Chan, C. 2018. "Work Experience Should Be a Job Requirement for Academics." Times Higher Education. Accessed March 2019. https://www.timeshighereducation.com/opinion/work-experience-should-be-job-requirement-academics.

Collini, S. 2018. Speaking of Universities. New York: Verso.

Collins, K., and J. Davies. 2009. "Feedback Through Student Essay Competitions: What Makes a Good Engineering Lecturer?" Engineering Education 4 (1): 8-15.

Cotton, D., W. Miller, and P. Kneale. 2017. "The Cinderella of Academia: Is Higher Education Pedagogic Research Undervalued in UK Research Assessment?" Studies in Higher Education, 1-12. doi:10.1080/03075079.2016.1276549.

Cox, R. D. 2009. Fear Factor: How Students and Professors Misunderstand One Another. Cambridge: Harvard University Press.

Cui, V., A. French, and M. O'Leary. 2019. "A Missed Opportunity? How the UK's Teaching Excellence Framework Fails to Capture the Voice of University Staff." Studies in Higher Education, doi:10.1080/03075079.2019.1704721.

Dakovic, G., and T. Loukkaola. 2017. "EUA's Learning and Teaching Initiative: Report from the 2017 Thematic Peer Groups." Accessed May 2019. https://eua.eu/resources/publications/348:eua\%E2\%80\%99s-learning-and-teachinginitiative-reportfrom-the-thematic-peer-groups.html.

Dearing, R. 1997. The Dearing Report. The National Committee of Enquiry into Higher Education. London: Her Majesty's Stationary Office. http://www.educationengland.org.uk/.

Elton, L. 2009. "Guiding Students Into a Discipline: The Significance of the Student's View." In The University and its Disciplines: Teaching and Learning Within and Beyond Disciplinary Boundaries, edited by Carolin Kreber, 129-139. New York: Routledge.

Erickson, M., P. Hanna, and C. Walker. 2020. "The UK Higher Education Senior Management Survey: A Statactivist Response to Managerialist Governance." Studies in Higher Education, 1-18. doi:10:1080/03075079.2020.1712693. 
ESG. 2015. Standards and guidelines for quality assurance in the European higher education area. Brussels: European Association of Institutions in Higher Education. Accessed January 2020. http://www.enqa.eu/wp-content/uploads/2015/11/ESG 2015.pdf.

Fairclough, N. 1993. "Critical Discourse Analysis and the Marketization of Public Discourse: The Universities." Discourse \& Society 4 (2): 133-168. doi:10.1177/0957926593004002002.

Forster, A. M., N. Pilcher, S. Tennant, M. Murray, N. Craig, and A. Copping. 2017. "The Fall and Rise of Experiential Construction and Engineering Education: Decoupling and Recoupling Practice and Theory." Higher Education Pedagogies 2 (1): 79-100. doi:10.1080/23752696.2017.1338530.

Gerek, I. H., and I. E. Efeoglu. 2015. What Qualifications and Skills Are Important for Civil Engineers/ A Job Advertisement Analysis, Managing Intellectual Capital and Innovation for Sustainable and Inclusive Society, 27-29th May. Italy: Bari.

Ginsberg, B. 2011. The Fall of the Faculty. Oxford: Oxford University Press.

Gosling, D. 2010. “Professional Development for New Staff - How Mandatory Is Your Post Graduate Certificate?" Educational Developments 11 (1): 1-4.

Graham, R. 2016. Does Teaching Advance Your Academic Career? Interim Report on the Development of a Template for Evaluating Teaching Achievement. The Royal Academy of Engineering. Accessed May 2019. https://www.raeng.org.uk/RAE/media/Publications/Reports/RAoE-Temp-for-Evaluating-Teaching-Achievement D8.pdf.

Graham, R. 2018. The Career Framework for University Teaching: background and overview, The Royal Academy of Engineering. Accessed May 2019. https://www.raeng.org.uk/publications/reports/career-framework-for-university-teaching-backgroun.

Grant, W., and P. Sherrington. 2006. Managing Your Academic Career. New York: Palgrave Macmillan.

Gretton, S., and D. Raine. 2017. "Reward and Recognition for University Teaching in STEM Subjects." Journal of Further and Higher Education 41 (3): 301-313. doi:10.1080/0309877X.2015.1100714.

Gunn, A. 2018. "The UK Teaching Excellence Framework (TEF): The Development of a New Transparency Tool." In European Higher Education Area: The Impact of Past and Future Policies, edited by A. Curaj, L. Deca, and R. Pricopie, 505-526. Switzerland AG: SpringerLink.

Halsey, A. H., and M. A. Trow. 1971. The British Academics. London: Faber and Faber.

Hayward, N., and E. Ongaro. 2016. "Recruitment and Autonomy in English Universities." IUS Publication Network Review. Accessed March 2019. http://www.ius-publicum.com/repository/uploads/25 02201617 40-HAYWARD ONGARO.pdf.

HESA. 2018. HE Staff Data. Accessed May 2019. https://www.hesa.ac.uk/data-and-analysis/staff.

HMSO. 1963. "Higher Education: Report of the Committee Appointed by the Prime Minister Under the Chairmanship of Lord Robbins, 1961-63.".

Holligan, C., and Q. Shah. 2017. "Global Capitalism's Trojan Horse: Consumer Power and the National Student Survey in England." Power and Education 9 (2): 114-128. doi:10.1177/1757743817701159.

Hubble, S. 2017. "The Teaching Excellence Framework (TEF)." House of Commons Briefing Paper Number 07484. June 22. Accessed January 2020. https://researchbriefings.files.parliament.uk/documents/CBP-7848/CBP-7848.pdf.

Jump, P. 2013. "Evolution of the REF." Times Higher Education. Accessed March 2019 https://www.timeshighereducation.com/features/evolution-of-the-ref/2008100.article.

Kernohan, D. 2014. “After the Goldrush: 30 Years of Teaching Quality Enhancement." Accessed May 2019. https://wonkhe.com/blogs/after-the-goldrush-30-years-of-teaching-quality-enhancement/.

Kinchin, I. M., and D. B. Hay. 2007. "The Myth of the Research-Led Teacher." Teachers and Teaching: Theory and Practice 13 (1): 43-61.

Kneale, P., D. Cotton, and W. Miller. 2016. "REF2014: Higher Education Pedagogic Research and Impact." Accessed May 2019. https://www.heacademy.ac.uk/knowledge-hub/ref-2014-higher-education-pedagogic-research-and-impact.

Lavigne, E. 2016. "Deans as Advertised: A Content Analysis of Academic Deans' Job Announcements by Canadian Universities from 2011 through 2015." Paper presented at the annual meeting of the Canadian Society for the Study of Higher Education (CSSHE) Calgary, May 31.

Lewis, H. R. 2007. Excellence Without a Soul: Does Liberal Education Have a Future? New York: Public Affairs.

Macfarlane, B. 2015. "The Invention of Tradition: How 'researchers' Replaced Teachers." The Times Higher Education. Accessed May 2019. https://www.timeshighereducation.com/opinion/invention-tradition-how-researchers-replacedteachers.

McHanwell, S., and S. Robson. 2018. "Guiding Principles for Teaching Promotions." Higher Education Academy. https://www.heacademy.ac.uk/knowledge-hub/guiding-principles-teaching-promotions.

Metcalf, H., H. Rolfe, P. Stevens, and M. Weale. 2005. Recruitment and Retention of Academic Staff in Higher Education, Research Report RR658. National Institute of Economic and Social Research.

Murray, M., S. Tennant, A. Forster, N. Craig, A. Copping, and N. Pilcher. 2017. "Talk the Talk and Walk the Walk: Are Career Academics Gatekeepers to My Tacit Knowledge?" Journal of Perspectives in Applied Academic Practice 5 (2): $112-114$. doi:10.14297/ipaap.v5i2.268.

Norris, N. 1997. "Error, Bias and Validity in Qualitative Research." Educational Action Research 5 (1): $172-176$. doi:10.1080/09650799700200020.

Norton, A. 2013. Taking University Teaching Seriously. Grattan Institute. Accessed March 2019 https://grattan.edu.au/report/taking-university-teaching-seriously/.

Nuttall, J., M. Brennan, L. Zipin, K. Tuinamuana, and L. Cameron. 2013. "Lost in Production: the Erasure of the Teacher Educator in Australian University Job Advertisements." Journal of Education for Teaching 39 (3)): 329-343. doi:10.1080/02607476.2013.799849.

O'Leary, M., V. Cui, and A. French. 2019. Understanding, Recognising and Rewarding Teaching Quality in Higher Education: An Exploration of the Impact and Implications of the Teaching Excellence Framework. London: University \& College Union. Accessed March 2019.http://www.ucu.org.uk/media/10092/Impact-of-TEF-report-Feb-2019/pdf/ImpactofTEFreportFEb2019. 
Olive, V. 2017. "How Much is Too Much? Cross-subsidies from Teaching to Research in British Universities." Higher Education Policy Institute. Accessed January 2020. https://www.hepi.ac.uk/2017/11/09/much-much-cross-subsidiesteaching-research-britishuniversities/.

Perkins, G. 2019. "The Teaching Excellence Framework (TEF) and Its Impact on Academic Identity Within a Research-Intensive University." Higher Education Policy 32 (2): 297-319. doi:10.1057/s41307-018-0082-z.

Pilcher, N., A. Forster, S. Tennant, M. Murray, and N. Craig. 2017. "Problematising the 'Career Academic'in UK Construction and Engineering Education: Does the System Want What the System Gets?" European Journal of Engineering Education 42 (6): 1477-1495. doi:10.1080/03043797.2017.1306487.

Pitt, R., and I. Mewburn. 2016. "Academic Superheroes? A Critical Analysis of Academic job Descriptions." Journal of Higher Education Policy and Management 38 (1): 88-101. doi:10.1080/1360080X.2015.1126896.

Power, M. 2015. "How Accounting Begins: Object Formation and the Accretion of Infrastructure." Accounting, Organizations and Society 47: 43-55. ISSN 0361-3682.

REF. 2019. "REF 2019/01: Guidance on Submissions." Accessed August 2019. https://www.ref.ac.uk/media/1092/ref-2019 01guidance-on-submissions.pdf.

Robbins, L. 1963. Higher Education, Report of the Committee Appointed by the Prime Minister Under the Chairmanship of Lord Robbins. London: Her Majesty's Stationery Office.

Robinson, R. N. S., C. V. Arcodia, C. Tian, and P. Charlton. 2010. “Cookery Related Employment Vacancy Advertisements and Skills Shortages." International Journal of Contemporary Hospitality Management 22 (4): 483-499. doi:10.1108/09596111042703.

Royal Academy of Engineering. 2019. "Applicant Guidance Notes - Industrial Fellowships (2019/20)." https://www.raeng.org.uk/RAE/media/General/Grants\%20and\%20prizes/Support\%20for\%20research/Industrial\%20Fellowsh ips\%20Scheme/IFS-Applicant-Guidance-Notes-2019 1.pdf.

Schuster, J. H., and M. J. Finkelstein. 2006. The American Faculty: The Restructuring of Academic Work and Careers. Baltimore, MD: The Johns Hopkins University Press.

Stern, N. 2016. "Building on Success and Learning from Experience: An Independent Review of the Research Excellence Framework." Accessed March $2019 \quad$ https://assets.publishing.service.gov.uk/government/ uploads/system/uploads/attachment data/file/541338/ind-16-9-ref-stern-review.pdf.

Sue, F., and M. Wood. 2012. "What Makes a Good University Lecturer? Students' Perceptions of Teaching Excellence." Journal of Applied Research in Higher Education 4 (2): 142-155. doi:10.1108/17581181211273110.

Tennant, S., M. Murray, A. Forster, and N. Pilcher. 2015. "Hunt the Shadow not the Substance: The Rise of the Career Academic in Construction Education." Teaching in Higher Education 20 (7): 723-737. doi:10.1080/13562517.2015.1070342.

Tierney, A. 2019. "The Scholarship of Teaching and Learning and Pedagogic Research Within the Disciplines: Should It Be Included in the Research Excellence Framework?" Studies in Higher Education, doi:10.1080/03075079.2019.1574732.

University Grants Committee. 1964. Report of the Committee on University Teaching Methods, Chaired by Sir Edward Hale. London: HMSO.

Vivian, D., A. Skone James, D. Salamons, Z. Hazel, J. Felton, and S. Whittaker. 2019. Evaluation of Provider-level TEF 2016-17 (Year2) Measuring the initial impact of the TEF on the Higher Education landscape. Research report. Whitehall: Department for Education, UK Government. 